\title{
Materijalizam kao društvena vrijednost i poticaj namjerama iseljavanja iz Hrvatske
}

DOI: https://doi.org/10.11567/met.32.3.1

UDK: $366: 314.743(497.5)$

316.752:314.743(497.5)

Izvorni znanstveni rad

Primljeno: 14. 04. 2016.

Prihvaćeno: 10. 01. 2017.

\author{
Krešimir Peračković
}

Institut društvenih znanosti Ivo Pilar, Zagreb

Kreso.Perackovic@pilar.hr

\section{Stanko Rihtar}

Institut društvenih znanosti Ivo Pilar, Zagreb

Stanko.Rihtar@pilar.hr

\section{SAŽETAK}

U radu se razmatra materijalizam kao vrijednosna orijentacija i pozadina konzumerizma te se empirijski provjerava je li povezan s namjerama iseljavanja iz Hrvatske. Ciljevi su rada utvrditi koliko su materijalizam i namjere iseljavanja uopće prisutni u društvu, jesu li te pojave ravnomjerno raspoređene ili kovariraju s važnijim obilježjima koja bi mogla olakšati ili otežati usvajanje takvih vrijednosti i namjera. Razmatra se i međusobni odnos materijalizma i namjera iseljavanja, odnosno provjerava se je li materijalizam neovisan i relevantan poticaj iseljavanju u usporedbi s ostalim odrednicama koje bi ga mogle olakšati ili, suprotno, učiniti manje privlačnim. Anketno istraživanje na reprezentativnom uzorku punoljetnog stanovništva Hrvatske provedeno 2014. ( $\mathrm{N}=1000)$ pokazalo je da je u Hrvatskoj materijalizam, iako nije apsolutno visoko zastupljena vrijednost, razmjerno ravnomjerno raspoređen među stanovništvom, što znači da u većoj mjeri varira individualno nego u skladu sa statusnim obilježjima koja bi težnju za materijalnim dobrima mogla poticati ili biti njihovom posljedicom. Materijalističke vrijednosti nešto su istaknutije među mladima, koji su istodobno skloniji iseljavanju. $U$ tom se kontekstu pokazalo da je materijalizam relativno značajan i neovisan poticaj iseljavanju, pa se zaključuje da bi tu povezanost trebalo podrobnije ispitati s obzirom na relevantnost obaju fenomena u današnjemu hrvatskom društvu.

KLJUČNE RIJEČI: materijalizam, konzumerizam, društvene vrijednosti, iseljavanje iz Hrvatske, ekonomski migranti 


\section{UVOD}

Razmatranje i istraživanje materijalizma ima dugu tradiciju u društvenim znanostima, a samo je značenje pojma dvojako: može se odnositi na filozofski pravac (tumačenje svijeta) ili na vrijednost koja potiče težnju za posjedovanjem materijalnih dobara. Materijalistička filozofija počiva na tezi prema kojoj su ekonomski odnosi temeljni uzrok društvenih pojava, u opreci prema idealističkim tumačenjima, koja taj status pridaju idejama (Abercrombie, Hill i Turner, 2008). U tom je kontekstu najpoznatija i po posljedicama najozbiljnija Marxova teorija o historijskome materijalizmu, ideološki temelj socijalističkih i komunističkih režima, prema kojoj dijalektika materije određuje dijalektiku duha (oprečno Hegelovu idealizmu), odnosno način proizvodnje materijalnih dobara oblikuje svekoliku društvenu nadgradnju (kulturno, strukturno i institucionalno). Suvremenija određenja materijalizma ne uključuju aksiološke ambicije makroekonomskog determinizma materijalističke filozofije, nego pojam premještaju u sferu (individualnih ili kulturnih) vrijednosti, uglavnom kao opreku unutrašnjem razvoju motiviranom »višim « aspiracijama. Primjerice »Materijalizam znači tendenciju da se materijalno posjedovanje i fizička udobnost smatraju značajnijim od duhovnih vrijednosti« (Oxford Dictionaries) $)^{1}$, odnosno da je »Usmjerenost k posjedovanju materijalnih predmeta u suprotnosti s ostvarenjem duhovne, emocionalne ili intelektualne dobrobiti« (Workman i Lee, 2011, u: Nefat i Benazić, 2014: 243). Iako definicijâ društvenih vrijednosti općenito ne manjka, prigodno se upotrebljivom pokazuje ona Haralambosa i Healda (1989: 20): »Vrijednost je uvjerenje da je nešto dobro i poželjno. Ona određuje da je nešto važno dostojno truda i vrijedno zalaganja«. U tom je smislu materijalizam vjerovanje da je posjedovanje materijalnih predmeta važno, isplativo i vrijedno, a konzumerizam je (najprije kao kupnja, a potom kao konzumiranje) djelovanje usmjereno ostvarenju tih ciljeva. Konzumerizam je primjerice u sociologiji definiran kao »kultura u čijem je središtu promoviranje, prodaja i stjecanje potrošačkih dobara« (Bilton, Bonnett i Jones, 1987: 34). Stoga se materijalizam može smatrati »infrastrukturnom « vrijednošću suvremene konzumeristističke kulture ${ }^{2}$ na općoj razini, odnosno poticajem za potrošačko ponašanje na individualnoj, i to ponajprije za potrošnju koja

https://en.oxforddictionaries.com/definition/materialism.

2 U novijoj literaturi konzumerizam se najčešće razmatra kao suvremena ideologija koja potiče potrošnju. Obrazlažući takav pristup, Hromadžić smatra da se pritom zagovara teza prema kojoj je konzumerizam više od pukog proizvodnog niza potrošačkih praksi, ali i više od zbroja pokreta, udruga, strategija i taktika kojima potrošači nastoje realizirati svoja prava u srazu s proizvođačima i ponuđačima roba i usluga (Hromadžić, 2008). 
nadilazi zadovoljavanje osnovnih potreba ljudi kao vrste, poput egzistencijalne potrebe za materijom i energijom.

No da bi se ostvario određeni potrošački standard odnosno osigurao pristup materijalnim dobrima i uspinjalo na "potrošačkim stepenicama«, ${ }^{3}$ nužna su tzv. sredstva za potrošnju, ${ }_{1}^{4}$ koja nerijetko nije moguće osigurati u uvjetima u kojima se živi. Stoga se kao jedan od najvažnijih motiva ekonomskih migracija pojavljuje težnja za poboljšanjem uvjeta, većom zaradom i općenito boljom kvalitetom života. Time horizontalna mobilnost - iseljavanje - postaje sredstvo koje osigurava i vertikalnu socijalnu mobilnost, bez obzira na to je li cilj veći prihod, status ili ugled kojima teži pojedinac spreman na odlazak iz zemlje podrijetla. U tom pogledu materijalizam igra dvostruku ulogu: s jedne je strane infrastrukturna vrijednost konzumerističke kulture, a s druge mogući poticaj iseljavanju. Pitanje jesu li materijalizam i iseljavanje povezani, odnosno potiče li materijalizam iseljavanje ako se njime potaknute težnje ne mogu ostvariti »lokalno«, glavna je tema koja je u ovom radu empirijski provjerena.

\section{MATERIJALIZAM KAO VRIJEDNOSNI OKVIR KONZUMERIZMA}

Kao što je u prethodnom poglavlju opisano, materijalizam i konzumerizam srodni su, ali nisu isti pojmovi i materijalizam se vezuje uz individualne vrijednosti i ponašanja, dok je »konzumerizam vjerovanje da ekonomski napredak i veća potrošnja pridonose društvenoj dobiti« (Tatzel, 2014, u: Nefat, 2016: 352) Iako u posljednjih dvadesetak godina teorijsko i istraživačko zanimanje za fenomene konzumerizma i potrošnje sve više rastu i šire se među različitim znanstvenim disciplinama, zanimljivo je da je od samog nastanka i razvoja industrijskog društva, posebno u 19. i 20. stoljeću, in-

3 Peračković (2013) u članku »Osnovni pojmovi u sociologiji potrošnje« opisuje tzv. model potrošačkih stepenica D. Bella: 1) na najnižem su stupnju društvenog razvoja djelovanja kojima se osiguravaju osnovna životna sredstva nužna za opstanak; 2) na drugoj stepenici pojavljuju se potrebe i djelovanja koja ih zadovoljavaju; 3) na trećoj su želje; 4) na četvrtoj su djelovanja koja su moguća uslijed preostalog (viška) dohotka nakon podmirenja troškova (npr. putovanja, hobiji i kupnja nakita); 5) na petoj je stepenici luksuz koji se očituje u stvaranju životnog stila distanciranog od ostalih kroz prepoznatljive i nedohvatljive luksuzne robe i usluge, npr. sofisticirani automobili, opremljene kuće, skupe slike, jahte itd. (Bell, 1999).

4 Osim novca kao temeljnog sredstva za potrošnju Ritzer taj pojam proširuje i govori o »novim sredstvima za potrošnju « ili »katedralama potrošnje« koje definira kao »mjesta koja omogućuju pristup robama i uslugama, koja potrošačima daju ono što žele, koja kreiraju njihove potrošačke želje, a koja su isplanirana, dizajnirana i upravljana na način da potiču potrošnju « (Rizter, 2005). Paradigma novih sredstava za potrošnju jesu suvremeni trgovački centri (Burić, 2013). 
dustrijska proizvodnja kao tema uglavnom dominirala u ekonomiji i sociologiji. Potrošnja je, premda je riječ o završnom činu u kojem proizvodnja ostvaruje vlastitu svrhu, bila marginalizirana ili potpuno izostavljena (Peračković, 2013; Corrigan, 1997).

Klasični teoretičari i rani istraživači novonastale društvene strukture industrijskog društva ponajviše su se usmjerili na problematiku ljudskog rada, njegove podjele, industrijsku proizvodnju, materijalizam i materijalnu kulturu, razmatrajući klasne i industrijske odnose i slično. Potrošnja se, kako je navedeno, uopće ne analizira i rijetko se spominje, iako je industrijska revolucija, između ostaloga, masovnom proizvodnjom (a time i pojeftinjenjem) pretvorila upotrebne predmete $\mathrm{u}$ robu široke potrošnje (Corrigan, 1997; Lipovetsky, 2008). Dostupnost materijalnih proizvoda, a poslije i usluga po znatno nižim cijenama omogućila je širim slojevima stanovništva konzumiranje onoga što je dotad bilo nedostupno. Zahvaljujući tomu masovna potrošnja poprima i simboličnu (identitetsku) dimenziju, koja se očituje kao oponašanje stila i načina života viših klasa (u sociološkoj literaturi nazvano »buržuiranje«; Haralambos i Heald, 1989: 66), a sličnu je pojavu opisao još i Veblen početkom 20. stoljeća u okviru »teorije upadljive potrošnje« (Veblen, 2008). Osim dostupnosti roba drugi važan poticaj nastanku potrošačkog društva svakako je i usporedni razvoj masovne i popularne kulture (uz uspon masovnih medija), što je pak pogodovalo nastanku onoga što se naziva »kulturnom industrijom « već u prvom dijelu 20. stoljeća (Adorno i Horkheimer, 1980).

Na kraju, razvoju potrošačkog društva potpomogli su i širenje privatnog vlasništva te individualizacija kao glavno obilježje, danas već dvostoljetnoga, modernoga industrijskog razdoblja. U takvim je okolnostima industrijska proizvodnja postala uvjetovana potrošnjom, pa je potrošnja postala i temeljni gospodarski pokretač. Ne ulazeći u temeljitiji pregled opsežne literature o potrošnji (za što bi zasigurno bila prikladnija izrada tematske bibliografije), može se izdvojiti tek povijesna analiza McKendricka i Plumba (1982) koja na primjeru Engleske pokazuje kako je ekonomski prosperitet još od 18. stoljeća omogućio dostupnost pomodnih dobara širim slojevima, što je argument kojim se industrijsku revoluciju istodobno može proglasiti i potrošačkom. Potrošnja u Engleskoj već tada prestaje biti rezervirana za aristokraciju i postaje masovna, a popularnu patinu među aristokratima zamjenjuje moda kao jedan od njezinih generatora. Upotrebna vrijednost postaje manje važnom od »modne vrijednosti«, ${ }^{5}$ a žene postaju glavni kupci kućan-

Iako Corrigan upotrebljava izraz »modna vrijednost« suprotstavljajući ga pojmu »upotrebna vrijednost«, važno je istaknuti da u klasičnoj teorijskoj tradiciji postoji poznata 
skih potrepština: od odjeće, namještaja, posuđa i zavjesa do sitnih modnih detalja, a uloga i sklonosti žena i danas su česta tema empirijskih istraživanja potrošnje i materijalizma kao svjetonazora (Nefat i Benazić, 2014; Richins i Dawson, 1992; Belk, 1984). Posjedovati ono što je moderno postalo je nužno obilježje društvenog statusa, a slijediti modu značilo je spremnost na kupnju novoga bez obzira na upotrebljivost ili očuvanost staroga.

Razmatrajući povijesne primjere razvoja potrošnje, Campbell (1987) dotiče se i potrošačke etike: što je ona i kako se očituje? Dok su tradicionalni potrošači orijentirani podmirivanju (osnovnijih) potreba, suvremeniji su motivirani širim i (samo)obnavljajućim spektrom želja i žudnji: stalno žudjeti za nečim i težiti nečemu postalo je kulturnim imperativom i samo sebi svrhom. Tu srž potrošačke kulture, utemeljene na materijalističkim vrijednostima, Campbell naziva romantičarskom etikom, koja je ponikla i raste izdvajanjem i razvojem ideje sebstva koje si udovoljava (i kompenzira izdvojenost) posjedovanjem materijalnih predmeta. Weberova protestantska etika samosvladavanja, askeze, odricanja i štednje tipična za rani kapitalizam (vrijeme stvaranja) zamijenjena je načelom užitka, odnosno hedonističkog udovoljavanja sebi kroz posjedovanje materijalnih dobara, što je postalo ciljem i »etičkim imperativom « djelovanja u kasnom kapitalizmu (vremenu trošenja). Tako je materijalizam prešao put od usmjerenja zadovoljavanju bioloških ili nižih potreba (na razini organizma) do usmjerenja zadovoljavanju simboličnih ili identitetskih potreba, ali i želja i žudnji te postao temeljnim vrijednosnim okvirom koji usmjeruje potrošačke prakse $u$ današnjoj kulturi konzumerizma. ${ }^{6}$ Iako Corrigan u djelu The Sociology of Consumption (1997) podsjeća da je materijalna potrošnja u nekom obliku oduvijek pri-

dihotomija: upotrebna vrijednost i razmjenska vrijednost, što su zapravo dva svojstva robe prema Marxovoj teoriji. Korisnost neke stvari čini tu stvar upotrebnom vrijednošću, a kad se promatra upotrebna vrijednost, uvijek se pretpostavlja kvalitativna određenost stvari i ostvaruje se samo upotrebom ili trošenjem, dok se razmjenska vrijednost pokazuje prije svega kao kvantitativni odnos, kao razmjer u kojem su upotrebne vrijednosti jedne vrste razmjenjuju za upotrebne vrijednosti druge vrste (Marx i Engels, 1978). Polazeći od te dihotomije i kroz njezinu kritiku i odmak, Baudrillard razvija tezu o simboličnoj vrijednosti te tvrdi da roba više nije određena svojom upotrebnom vrijednošću, nego onim što označuje, a ono što označuje više nije ono kako djeluje, »nego kompleksan odnos naspram cjelokupnog totaliteta roba i znakova« (Baudrillard, 1998, u: Maslov, 2009: 100).

6 Suvremena psihologija razlikuje potrebe od želja i definira potrebe kao motivacijska stanja nužna za opstanak pojedinca ili organizacije, dok su želje usmjerene prema objektima koji bi život učinili ugodnijim ili bi olakšali izvođenje određenih aktivnosti (Milas, 2007). U svojoj analizi potrošačkoga kapitalizma kao epohe produkcije imaginarija potrošačke želje Hromadžić govori o »simptomu potrošačke žudnje« koji je redovito izazvan »simboličkim posredovanjem i stimulacijom znakova upakiranih u formi reklamno-marketinške propagande - fenomen podsvjesno-iracionalnoga karaktera manifestiran na razini pojedinca (Hromadžić, 2012: 57). 
sutna u svim kulturama, ona je tek tijekom 20. stoljeća poprimila masovne razmjere i postala globalnim i univerzalnim kulturnim fenomenom. Iako je ponikao u kapitalističkim društvima zapada, konzumerizam nije zaobišao ni postsocijalističke zemlje. Hrvatska primjerice već u razdoblju socijalizma djelomice poprima obilježja potrošačkog društva ${ }^{7}$ - potrošnju i potrošački način života poticala je i vladajuća partija još od šezdesetih i sedamdesetih godina prošlog stoljeća (Duda, 2005, 2010). Stoga se ovdje prije može govoriti o kontinuitetu nego o tranzicijskom diskontinuitetu, tipičnijem za zemlje u kojima se živjelo iza »željezne zavjese«. ${ }^{8}$

\section{ISELJAVANJE IZ HRVATSKE - VANJSKE MIGRACIJE KAO POTRAGA ZA BOLJIM ŽIVOTOM}

Osim što konzumerizam, kao globalno relevantan fenomen, tijekom posljednjih desetljeća obilježava i Hrvatsku, u njoj je znatno duže prisutan i drugi relevantan, ali manje univerzalan fenomen - vanjske migracije odnosno iseljavanje stanovništva. Hrvatska je »tradicionalno « iseljenička zemlja i spada među one s najnepovoljnijim omjerom iseljenoga i rezidencijalnoga stanovništva; prema nekim izvorima, računa se da je broj iseljenika podjednak broju onih koji danas žive u Hrvatskoj. ${ }^{9}$ Da emigracija nije imala takve razmjere i da ne traje više od stoljeća, demografske analize pokazuju da bi Hrvatska 2001. imala najmanje 6,22 milijuna stanovnika, ili 40,1\% više od popisanoga broja (Nejašmić, 2014). Ako se uzme u obzir duže povijesno razdoblje, još od osmanskih i ostalih osvajanja (samo je osmanska prijetnja trajala četiri stoljeća, uključujući stogodišnji rat) preko svjetskih ratova pa do Domovinskog rata krajem 20. stoljeća, možemo reći kako je taj geostrateški položaj, u prostoru međucivilizacijskih sukoba i nadigravanja velikih političkih sila, Hrvatskoj namijenio dugotrajnu sudbinu (st)ratišta, pa se često (prisilno) iseljavalo radi spašavanja života (Rogić, 2000). Osim toga deficitarna tehnička modernizacija i narav državnih saveza u koje je ulazila (i u

7 Budući da u ovom radu ne možemo ulaziti u temeljiti pregled dosad objavljenih radova o temi konzumerizma i materijalizma, za što bi zasigurno bila adekvatnija izrada bibliografije, važno je spomenuti da je u posljednjih desetak godina među domaćim sociolozima i antropolozima došlo do povećanog interesa za tu temu, pa se za detaljnije uvide preporučuju primjerice: Čolić, 2008; Hromadžić, 2008; Duda, 2010; Burić, 2010; Stanić, 2011; Peračković, 2013; Nefat i Benazić, 2014.

8 Iako u literaturi nema općeprihvaćene definicije pojma »željezne zavjese«, autori koji su se tom tematikom bavili uglavnom ističu da je riječ o poslijeratnoj političkoj povijesti nakon Drugoga svjetskog rata u Europi koja je obilježena raskolom totalitarnoga istočnog svijeta od demokratskog svijeta Zapada, čiji je simbol bio Berlinski zid (Mileta, 1997).

9 Izvor: http://www.hia.com.hr/iseljenici-statistika.html. 
kojima je igrala sekundarnu političku ulogu) repertoar motiva za odlaskom učinile su potpunim: osim da bi se spasio život, iseljavalo se (dobrovoljno) zbog ekonomskih, političkih i karijernih razloga (Rogić i Čizmić, 2011) $\cdot{ }^{10} \mathrm{Uz}$ demografski pristup migracijama, sociologija migracija bavi se širim kontekstom i društvenim čimbenicima koji su u pozadini migracija, između ostaloga i istraživanjima motiva samih migranata (npr. Mesić, 2002; Mežnarić, 1991; Mesić i sur., 1991; Katunarić, 1974). Domaća literatura koja se bavi tom temom nije oskudna, no nedostaju istraživanja i analize koji bi se podrobnije bavili novim valom iseljavanja iz Hrvatske u posljednjih nekoliko godina, posebno nakon ulaska u EU. Ipak, valja reći da je trajno obilježje dobrovoljnih i ekonomskih migracija iz Hrvatske, odnosno privlačni faktor (pull), veća zarada, ponajprije u zapadnoeuropskim zemljama i u SAD-u. Primjerice Mesić ističe da se već krajem šezdesetih iseljavao najagilniji dio radne snage (među njima i znatni dio već zaposlenih), uglavnom kvalificiranih i visokokvalificiranih radnika. Jedno anketno istraživanje iz 1971. pokazalo je da je čak $77 \%$ iseljenih prethodno već bilo zaposleno te da im je glavni motiv odlaska potraga za većom zaradom (Mesić, 1991). Teza da je nezaposlenost glavni uzrok migriranja ni tada se nije pokazala točnom, a i danas je važno pitanje odlazi li se ponajprije zbog »preživljavanja«ili težnje za »viškom« (materijalnim i/ili profesionalnim).

$\mathrm{U}$ odnosu na spomenuto razdoblje iseljavanje se danas odvija u bitno promijenjenom kontekstu. Globalna gospodarska kriza, koja je zahvatila i Hrvatsku, nije možda toliko bitna ako se vodi računa o tomu da je ona (ili manjak profesionalnih perspektiva) zbog nedovoljne gospodarske razvijenosti u Hrvatskoj zapravo »trajno stanje«. No politički kontekst bitno je drukčiji: nakon promjene sustava, a posebno nakon ulaska u EU, prepreke mobilnosti gotovo da su ukinute, što je vjerojatno i potaknulo novi val iseljavanja.

Prema dijelu medijskih napisa, $u$ tom je pogledu situacija alarmantna: barata se velikim brojevima (sve do dvjesto tisuća), no statistički podaci to ne potvrđuju. Prema godišnjim evidencijama Državnog zavoda za statistiku, 2013. iselile su se 15.262 osobe, 2014. godine 20.858 i 2015. njih 29.651

10 Tipologija migracija najčešće se kreira prema kriterijima: 1) državnih granica (vanjske i unutarnje), 2) vremena (definitivne tj. konačne i privremene - sezonske i dnevne), 3) uzroka (ekonomske i neekonomske - političke, ekološke, individualno-psihološke), 4) dobrovoljnosti (dobrovoljne i prisilne) i 5) organiziranosti (organizirane i spontane). Migracije stanovništva jedno su od temeljnih područja istraživanja kojima se bavi demografija i podrazumijevaju mehaničko kretanje stanovništva odnosno preseljenje osoba iz rodnog mjesta ili prethodnog mjesta stalnog boravka u mjesto doseljenja ili u novo mjesto boravka pod uvjetom da je riječ o preseljenju trajnoga karaktera (Wertheimer-Baletić, 1999). 
(Državni zavod za statistiku, 2014, 2015, 2016). Navedene se evidencije zasnivaju na podacima MUP-a o odjavama prebivališta. Budući da te promjene dio iseljenih ne prijavljuje (barem ne odmah), valja pretpostaviti da je riječ o konzervativnoj procjeni - iseljenih je zasigurno više, no koliko točno, ne može se utvrditi jer nitko ne vodi precizne službene evidencije (primjerice u Hrvatskoj ne postoji registar stanovništva). Prema medijski dostupnim analizama stručnjaka, primjerice onoj Župarić-Iljića (Institut za migracije i narodnosti) predočenoj na javnoj tribini Iseljavanje iz Hrvatske nakon pristupanja EU - moguće posljedice (održanoj u listopadu 2016. u Vukovaru), navedeni podaci nisu katastrofalni, pogotovo ako se usporede $s$ višemilijunskim odlascima iz Poljske ili Rumunjske nakon pristupanja EU-u. No zabrinjavajući su: trend je u porastu (što se jasno vidi iz statističke evidencije), nerijetko odlaze cijele obitelji (a ne samo »glave« kao prije), a dio iseljenih ne namjerava se vratiti. ${ }^{11}$

Iako je i iseljavanje nezaposlenog stanovništva, tj. onoga koje ide »trbuhom za kruhom «, štetno, masovnije iseljavanje visokoobrazovanih (pa i već zaposlenih) stručnjaka, tj. »odljev mozgova «, štetno je u još većoj mjeri jer je šteta koju nanosi dvostruka: prvo, umanjuje razvojne potencijale i kvalitetu života u lokalnim zajednicama i, drugo, ulaganje u školovanje onih koji su otišli pretvara se u uzaludnu investiciju.

Osim spomenutih objektivnih okolnosti aktualnom iseljavanju mogla bi pogodovati i sklonost materijalizmu kao latentni motiv. Budući da istraživanja o motivima toga novog iseljavanja nema, pitanje je pridružuje li se materijalizam u novije vrijeme, ako je već postao univerzalnom vrijednošću potrošačkih društava, tradicionalnijim motivima iseljavanja i potrage za boljim standardom i/ili karijerom u zemljama koje nude bolju perspektivu.

11 Zbog relevantnosti fenomena i manjka preciznih službenih evidencija, poput registra stanovništva, u što skorijoj budućnosti bilo bi nužno provesti sveobuhvatno istraživanje o hrvatskim građanima koji su emigrirali, osobito nakon ulaska u EU, koje bi vodilo računa o strukturi emigranata i njihovoj motivaciji za iseljavanje, kako bi se podrobnije elaborirali uzroci te povezanost namjera i stvarnog iseljavanja. 


\section{CILJEVI ISTRAŽIVANJA I METODA}

S obzirom na to da odnos materijalizma i namjera iseljavanja ${ }^{12}$ iz Hrvatske dosad nije empirijski ispitan, a kako je u oba slučaja riječ o relevantnim društvenim fenomenima, ciljevi su rada: prvo, utvrditi koliko su materijalizam i namjere iseljavanja uopće prisutni u društvu, jesu li te pojave ravnomjerno raspoređene ili kovariraju s važnijim obilježjima koja bi mogla olakšati ili otežati usvajanje takvih vrijednosti i namjera; drugo, utvrditi kakav je odnos materijalizma i namjera iseljavanja - je li materijalizam neovisan i relevantan poticaj iseljavanju $\mathrm{u}$ usporedbi s ostalim odrednicama koje bi ga mogle olakšati ili, suprotno, učiniti manje privlačnim.

Materijalizam se, operacionalno definiran, može ispitivati na sociokulturnoj (primjerice Belk, 1985) ili na individualno-psihološkoj razini, na kojoj se najčešće provjerava kako materijalističke vrijednosti utječu na potrošačku praksu, kakva im je važnost u svakodnevnom životu te što potrošači kao pojedinci žele (Ahuvia i Wong, 2002). Prema pregledu Nefat i Benazića (2014), najčešće upotrebljavan instrument $u$ empirijskim istraživanjima ljestvica je Richins i Dawsona (1992) koji smatraju da identificiranje aspekata individualnog materijalizma pruža uvid u to kako je konfiguriran na višoj ili kulturnoj razini (uključujući primjerice interakciju s marketinškim aktivnostima, pogotovo oglašavanjem). Njihova operacionalna definicija, artikulirana u ljestvicu materijalističkih vrijednosti (Material Values Scale, MVS), uključuje tri dimenzije: posjedovanje materijalnih dobara kojim se procjenjuje (1) osobni uspjeh i uspjeh drugih ljudi, (2) središnje mjesto posjedovanja u životu osobe i uvjerenje kako posjedovanje i ono što ono osigurava vodi prema (3) sreći i životnom zadovoljstvu. MVS se izvorno sastoji od osamnaest čestica. Naknadno je razvijena i kraća verzija od devet čestica (Richins, 2004: 210) koja je upotrijebljena i u ovom istraživanju.

Podaci za analizu prikupljeni su usmenom terenskom anketom $(\mathrm{N}=$ 1000) provedenom tijekom travnja 2014. na reprezentativnom uzorku punoljetnog stanovništva Hrvatske u sklopu projekta Pilarov barometar hrvatskoga

12 Važno je istaknuti da namjera iseljavanja nije uvijek korelirana sa stvarnom migracijom. Božić i Burić (2005) u članku »Migracijski potencijal Hrvatske - mikroanalitički aspekti« opisuju Kriegerov (2004) model istraživanja migracijskog potencijala koji polazi od razlike procesa aktualizacije i realizacije migracije: u početnoj fazi postoje inercija i nevoljkost iseljenja; $u$ drugoj se fazi početna "prirodna inercija prevladava te se mogućnost migriranja stavlja u alternativu mogućih akcija; sljedeći je korak razvoj konkretne namjere da se migrira, kada se uspoređuju druge mogućnosti te se na kraju razvija i migracijsko ponašanje; stoga Krieger »mjeri stavove prema mogućoj migraciji na tri razine - na općoj sklonosti prema migriranju, na temeljnoj namjeri prema migriranju te na čvrstoj namjeri migracije« (Božić i Burić, 2005: 14). 
društva (Rihtar, 2014). Kako je navedeno, kao mjera materijalizma upotrijebljena je skraćena verzija ljestvice Richins i Dawsona u obliku tvrdnji (npr. »Volim imati stvari koje impresioniraju ljude«) s kojima se moglo složiti ili ne složiti u rasponu od 1 (Uopće se ne slažem) do 5 (Potpuno se slažem). Namjere iseljavanja ispitane su na ljestvici u rasponu od 1 (Uopće o tomu ne razmišljam) do 4 (Planiram, svakako želim otići). Sociodemografski status provjeren je sljedećim pokazateljima: spol (1 - muški, 2 - ženski), dob u kategorijama od 1 (od 18 do 30 godina) do 6 (71 i više godina) i obrazovanje (1 - NSS, 2 - SSS, 3 - VSS). Osim sociodemografskog statusa u užem smislu, ispitana je i situiranost: materijalna (prihodi po članu kućanstva na ljestvici u rasponu od 1 - manje od $500 \mathrm{kn}$ do 8 - više od $5000 \mathrm{kn}$ ), profesionalna ( 0 - nije zaposlen/a, 1 - zaposlen/a) te bračna i obiteljska ( 0 - nije u braku, 1 - oženjen/udana; 0 - nema ili 1 -ima djecu). Usto, provjereno je živi li već netko iz obitelji u inozemstvu ( 0 - ne živi, 1 - iseljen jedan ili više članova u razvijenije zemlje) kao jedan od mogućih čimbenika koji bi, uz rezidencijalni status (1 - Zagreb, 2 - veliki gradovi, 3 - manji gradovi, 4- ostala naselja), mogao utjecati na odluku o odlasku.

Osim objektivnih obilježja zabilježeni su i subjektivni pogledi na društvenu i osobnu stvarnost: ocjena opće situacije u Hrvatskoj ispitana je ljestvicom u rasponu od 1 (Vrlo loša) do 5 (Vrlo dobra); zadovoljstvo gospodarskom situacijom ljestvicom u rasponu od 0 (Uopće nisam zadovoljan/ na) do 10 (Izrazito sam zadovoljan/na), a zadovoljstvo vlastitim standardom ispitano je ljestvicom istog raspona, od 0 (izrazito nezadovoljan/na) do 10 (izrazito zadovoljan/na). Na kraju, kao potencijalni važniji atenuator materijalizma provjeren je i stupanj religioznosti na ljestvici istog formata, od 0 (uopće nisam religiozan/na) do 10 (izrazito sam religiozan/na).

\section{REZULTATI I RASPRAVA}

Trodimenzionalna struktura Richinsine ljestvice, kako pokazuju nedavne analize u Hrvatskoj (Dević, Majetić i Krnić, 2015; Kaliterna Lipovčan, Prizmić-Larsen i Brkljačić, 2015) i još nekim europskim (Müller i sur., 2013) ili azijskim zemljama (Wong, Rindfleisch i Burroughs, 2003) nije se pokazala međukulturno robusnom, odnosno latentna struktura nije kongruentna, a teorijski pretpostavljen broj faktora varira u različitim istraživanjima. Ljestvica je primarno namijenjena istraživanju materijalizma američkoga srednjeg sloja, pa neke doslovno prevedene tvrdnje ne zadržavaju isto značenje u zemljama manje okrenutim konzumerizmu ili u onima u kojima je standard niži. Primjerice tvrdnja »Moj život bio bi bolji kad bih imao/la određene 
stvari koje nemam«, ako su zadovoljene osnovne potrebe, može upućivati na materijalizam kao vrijednost, a ako nisu, i na deprivaciju osnovni(ji)h potreba (jer pojam »stvar« nije preciznije definiran, pa se ne može razlikovati njezinu upotrebnu od simbolične vrijednosti). Zbog spomenutog razloga, ali i nekih psihometrijskih nedostataka (reverzna artikulacija čestica) međukulturna primjena ljestvice uglavnom ne daje trodimenzionalnu, nego dvodimenzionalnu strukturu. To vrijedi i za Hrvatsku (Dević, Majetić i Krnić, 2015; Kaliterna Lipovčan, Prizmić-Larsen i Brkljačić, 2015), u kojoj se pokazalo da je takva struktura uglavnom odraz kombinacije deprivacije i materijalizma.

Vodeći računa o tomu, za potrebe ove analize upotrijebljene su čestice iste ljestvice nekontaminirane deprivacijom. Iako ne odražavaju teorijsku namjeru autora (trodimenzionalni konstrukt), pokazalo se da čine upotrebljivu i pouzdanu ad hoc jednodimenzionalnu ljestvicu, dovoljnu za analitičke potrebe ovog rada (tablica 1$).{ }^{13}$

Tablica 1. Struktura (analiza glavnih komponenata) i pouzdanost ad-hoc ljestvice materijalizma

Table 1. Structure (principle components analysis) and reliability of adhoc materialism scale

Tvrdnje (dio čestica Richinsine ljestvice)

GK 1

Divim se ljudima koji imaju luksuzne stanove, automobile i odjeću.

0,735

Kad su u pitanju stvari koje posjedujem, trudim se voditi jednostavan život.*

0,416

Kupovanje mi pruža veliko zadovoljstvo.

0,709

Volim imati stvari koje impresioniraju ljude.

0,874

Volio/voljela bih živjeti vrlo luksuzno.

0,835

Ukupno objašnjene varijance (\%)

53,551

Pouzdanost (Cronbachov alfa koeficijent)

0,772

* Reskalirani odgovori.

13 Nova je ljestvica izračunata u obliku prosječnih skalnih vrijednosti (zbroj rezultata na izabrane četiri čestice podijeljen s njihovim brojem), čime je zadržan raspon od 1 do 5 (veći rezultat na toj ljestvici znači istaknutiji materijalizam kao vrijednost). 
Izračunati prosjek (aritmetička sredina) ovako konstruirane ljestvice materijalizma iznosi 2,32. Ako se taj prosjek usporedi s apriornim ili teorijskim, koji iznosi 3 (raspon 1 -5), može se reći da je materijalizam kao vrijednost među stanovništvom slabo do umjereno izražen. Sličan nalaz navode i autori koji su upotrijebili različite kombinacije čestica Richinsine ljestvice u istraživanjima na općoj populaciji (Dević, Majetić i Krnić, 2015; Kaliterna Lipovčan, Prizmić-Larsen i Brkljačić, 2015) ili među studentima (Nefat i Benazić, 2014). Kad je riječ o statusnim obilježjima, ovo istraživanje pokazuje da je materijalizam ponajviše povezan s dobi - skloniji su mu mlađi (tablica 2), a u vrlo maloj mjeri i obrazovaniji, zaposleni te oni koji su relativno zadovoljniji vlastitim standardom (no ne i objektivno viših prihoda). Ulazak u brak, dobivanje djece i religioznost donekle smanjuju materijalističke sklonosti, dok spol s njima nije značajno povezan. Iako su korelacije između nabrojenih obilježja i materijalizma značajne (zbog veličine uzorka), vrlo su niske i upućuju na tek blago izražene populacijske varijacije.

Tablica 2. Povezanost materijalizma sa subjektivnim i objektivnim obilježjima ispitanika

Table 2. Correlations between materialism and subjective and objective characteristics of respondents

\begin{tabular}{ll}
\hline Obilježja & Povezanost s materijalizmom (r) \\
\hline Spol & 0,005 \\
\hline Dob & $-0,237^{* *}$ \\
\hline Obrazovanje & $0,129^{* *}$ \\
\hline Brak & $-0,074^{*}$ \\
\hline Djeca & $-0,161^{* *}$ \\
\hline Zaposlenost & $0,080^{*}$ \\
\hline Prihodi & 0,052 \\
\hline Zadovoljstvo vlastitim standardom & $0,069^{*}$ \\
\hline Religioznost & $-0,075^{*}$ \\
\hline
\end{tabular}

${ }^{*} p<0,05 ;{ }^{* *} p<0,01$ 
No kako sve ono što je povezano s materijalizmom, bilo pozitivno (obrazovanje, zaposlenost, zadovoljstvo standardom), bilo negativno (brak, djeca, religioznost), u određenoj mjeri ovisi i o dobi, ako se parcijalizira njezin utjecaj, ionako niska povezanost između spomenutih varijabli i materijalizma nestaje (obrazovanje: $r_{p}=-0,046 ; p=0,192$; zaposlenost: $r_{p}=-0,031 ; p$ $=0,385$; zadovoljstvo standardom: $r_{p}=0,061 ; p=0,083 ;$ brak: $r_{p}=-0,028 ; p$ $=0,428$; djeca: $r_{p}=-0,028 ; p=0,426$; religioznost: $\left.r_{p}=-0,014 ; p=0,686\right)$. Veća sklonost materijalizmu među mlađima vjerojatno je posljedica više uzroka, od kojih se mogu izdvojiti dva. Prvo, akumuliranje životnog iskustva i odgovornosti, neovisno o tomu koliko se steklo, može promijeniti status materijalizma u hijerarhiji vrijednosti spuštajući ga na niže mjesto. Drugo, posjedovanje u starijoj dobi može izgubiti i simboličnu vrijednost, koja je zasigurno relevantnija pri formiranju identiteta, odnosno pri potrazi za statusom i mjestom u društvu među mladima. Izuzme li se (donekle) dob, većina ostalih istraživanja ne pokazuje ni istaknut ni dosljedan odnos statusnih obilježja i materijalizma (Kamano, 1999; vidjeti i pregled Dević, Majetić i Krnić, 2015). Uzevši u obzir to, kao i vrlo niske (ili parcijalno neznačajne) korelacije zabilježene $u$ ovom istraživanju, bez velikih se ograda može ustvrditi da je materijalizam razmjerno ravnomjerno prihvaćena vrijednost u statusno različitim skupinama (iako ne u apsolutno velikoj mjeri), odnosno da ponajprije varira - individualno, neovisno o očekivanju da bi status mogao pomoći usvajanju takve orijentacije ili obratno, da bi takva orijentacija mogla pomoći postizanju statusa. A na individualnoj razini, kako se pokazuje, materijalizam kao vrijednost ne pridonosi osjećaju dobrobiti (Kaliterna Lipovčan, Prizmić-Larsen i Brkljačić, 2015), kao što ni rano usvojeni materijalistički ciljevi ne pridonose zadovoljstvu životom, pogotovo ako se usporede s usmjerenošću angažiranome ili smislenom postojanju (Brdar i Anić, 2010). Dosljedno tomu, materijalizam (i učestalija potrošnja) donekle je povezan i sa socijalnom neosjetljivošću: skloniji su mu oni koji više cijene postignuće, moć ili hedonizam nego dobrohotnost ili univerzalizam (Segvili i Cesur, 2014; Dević, Majetić i Krnić, 2015).

\section{Materijalizam i namjere iseljavanja}

U vrijeme istraživanja (travanj 2014.) udio onih koji se ozbiljnije namjeravaju iseliti (često razmišljaju o tomu ili to ozbiljno planiraju) u cijeloj je populaciji iznosio nešto manje od $15 \%$, pri čemu se pokazalo da odnos dobi, kao glavne odrednice iseljavanja, i namjera odlaska nije linearan: nakon navršenih četrdeset godina te namjere naglo slabe (tablica 3). Konkretnije, go- 
tovo trećina mlađih o odlasku često razmišlja ili ga ozbiljnije planira, dok među starijima taj udio pada na šest posto.

Tablica 3. Dob i namjere iseljavanja (\%)

Table 3. Age and intentions to emigrate (\%)

\begin{tabular}{lcc}
\hline $\begin{array}{l}\text { »Planirate li u skorije vrijeme otići živjeti u } \\
\text { inozemstvo? }\end{array}$ & $<$ 40 godina & $>$ 40 godina \\
\hline Uopće ne planiram & 34,9 & 80,9 \\
\hline Ponekad razmišljam o tome, no radije bih ostao/la & 34,1 & 12,9 \\
\hline Često razmišljam o tome, rado bih otišao/la & 23,2 & 5,1 \\
\hline Planiram, svakako želim otići & 7,8 & 1,1 \\
\hline $\mathbf{N}$ & 330 & 670 \\
\hline
\end{tabular}

Vodeći računa o tomu da su namjere odlaska nakon četrdesete godine zanemarive, ${ }^{14}$ pitanje je potiče li materijalizam na iseljavanje $u$ mlađoj populaciji (u kojoj je i inače istaknutiji), i to u usporedbi s dvije vrste, objektivnih i subjektivnih, odrednica: prvo, onih koje bi iseljavanje mogle otežati, poput obiteljske, materijalne i profesionalne situiranosti, i, drugo, onih koje bi ga mogle potaknuti, poput obrazovanja, nezadovoljstva općom ili gospodarskom situacijom i perspektivama, nezadovoljstva vlastitim standardom, mogućeg oslonca na bliske osobe koje već žive u razvijenijim zemljama ili življenja u manjim mjestima koja ne nude očekivane perspektive. Odgovor na postavljeno pitanje daju rezultati regresijske analize (tablica 4), koja pokazuje da je materijalizam, u izabranome prediktivnom sklopu, relevantna (statistički značajna) odrednica iseljavanja.

14 Nakon četrdesete godine namjere iseljavanja naglo se smanjuju, no i među mlađim kohortama, onim do trideset i onim između trideset i četrdeset godina, postoje statistički značajne razlike. Kako pokazuje usporedba srednjih vrijednosti ljestvice namjera iseljavanja, skloniji su mu mlađi od trideset $(M=2,16)$ nego oni između trideset i četrdeset godina $(M$ $=1,82) ; \mathrm{t}=3,455 ; \mathrm{p}<0,01$. 
Tablica 4. Odrednice iseljavanja među mlađima od 40 godina

Table 4. Indicators of emigration among respondents younger than 40

\begin{tabular}{lc}
\hline Prediktori & $\beta$ \\
\hline Ocjena opće situacije u Hrvatskoj & $-0,007$ \\
\hline Zadovoljstvo gospodarskom situacijom u Hrvatskoj & $-0,029$ \\
\hline Prihodi po članu kućanstva & 0,055 \\
\hline Zadovoljstvo vlastitim standardom & $-0,135^{*}$ \\
\hline Obrazovanje & 0,087 \\
\hline Zaposlenost & $-0,249^{* *}$ \\
\hline Bračni status & 0,121 \\
\hline Djeca & $-0,185^{* *}$ \\
\hline Iseljen član/članovi obitelji & 0,047 \\
\hline Tip (veličina) naselja & $-0,056$ \\
\hline Materijalizam & $0,168^{* *}$ \\
\hline R & 0,395 \\
\hline$* 0,628^{* *}$ \\
\hline F
\end{tabular}

U tom pogledu ne konkuriraju mu ni obrazovanje i materijalni status, kao moguće glavne »objektivne « ili statusne odrednice odlaska u potragu za karijerom i/ili materijalnom situiranošću. Budući da materijalni status nije odrednica iseljavanja (a nije ni povezan s takvim namjerama, korelacija iznosi -0,030; p > 0,001), a subjektivno (ne)zadovoljstvo vlastitim standardom jest, razmjerno je jasno da razmišljanje o odlasku ne potiče apsolutna, nego relativna deprivacija: želja da se ima, može ili zaslužuje više, neovisno o tomu koliko se stvarno ima. A kako se vidi iz tablice 2, ta je želja, a ne stvarni prihodi, donekle povezana i s materijalističkim vrijednostima. 
U ovom se istraživanju pokazalo da je obrazovanje nisko povezano s namjerama iseljavanja $(r=0,162 ; \mathrm{p}<0,001)$, odnosno nešto su mu skloniji oni više naobrazbe, ali zbog konfiguracije korelacija s ostalim prediktorima i s kriterijem u regresijskome modelu gubi na konkuretnosti. No to ne umanjuje njegov potencijalni utjecaj na stvarni odlazak: moguće je da će se na taj korak u većem broju ipak odlučiti profesionalno kompetentniji, a ne svi oni koji su (kao u ovom istraživanju) samo iskazali želju ili ozbiljniju namjeru. Osim subjektivnog nezadovoljstva standardom i materijalističke orijentacije kao značajnih poticaja, životna situiranost odlazak čini manje poželjnim. Iseljavanju su manje skloni zaposleni, isto kao i oni koji su zasnovali obitelj, no ne kad uđu u brak, nego nakon što dobiju djecu. U izabranome prediktivnom kontekstu ocjena opće i gospodarske situacije, član(ovi) obitelji koji već žive u inozemstvu kao mogući oslonac i rezidencijalni status ne igraju relevantnu ulogu. Prema ocjeni situacije u društvu, oni koji namjeravaju otići ne razlikuju se posebno od onih koji o tome rijetko ili uopće ne razmišljaju (gotovo $90 \%$ mlađih od četrdeset godina opću i gospodarsku situaciju smatra uglavnom ili izrazito lošom), a odlasku je podjednako sklono mlađe stanovništvo koje živi u manjim i većim naseljima, iako onima koji žive u većima lokalna sredina pruža više mogućnosti (no očito ne i dovoljno).

Sagledano u cjelini, bez obzira na to što je regresijski model statistički značajan, ukupna determinacija namjera iseljavanja obuhvaćenim prediktorima nije posebno visoka. Stoga se može reći da su te namjere, poput materijalizma, prilično ravnomjerno zastupljene među mladima, no značajni koeficijenti ipak upućuju na (makar blago) izraženu hijerarhiju olakšavajućih i otegotnih okolnosti. U tom se pogledu materijalizam, neovisno o ostalim subjektivnim ili objektivnim odrednicama, pokazao robusnim poticajem koji se danas (u potrošačkom kontekstu) pridružuje tradicionalnijim motivima iseljavanja, poput težnji za ostvarivanjem karijernih ambicija i/ili poboljšanjem životnog standarda.

\section{ZAKLJUČAK}

Iako su materijalizam kao vrijednosna orijentacija i konzumerizam kao ideologija koja potiče potrošnju teme koje u suvremenim istraživanjima autori češće vežu uz potrošački kapitalizam (Lipovetsky, 2008; Campbell, 1987), težnja za boljim životnim uvjetima i kvalitetom života te većom zaradom, kojom se ne samo zadovoljavaju primarne potrebe nego se mogu ispuniti i želje i žudnje, jest tema koja se ne može svesti samo na fenomene suvremenoga konzumerizma ili pak na psihologiju potreba. Upravo migra- 
cije, osobito ekonomske i dobrovoljne, pokazuju da se ljudi ne mire samo s preživljavanjem i zadovoljenjem primarnih potreba, već ih pokreću želja i nada da će odlaskom i zaposlenjem u bogatijoj zemlji ostvariti taj ideal o boljem i višem, na bilo kojoj razini, pa su stoga migracije kao tip horizontalne socijalne mobilnosti u funkciji vertikalne mobilnosti kao životnog cilja pojedinca. Takva kretanja zapravo su stara kao i samo čovječanstvo, mijenjaju se samo sadržaji motiva te životne i povijesne okolnosti koje mogu biti katalizator i svojevrsni okidač (push faktor) za donošenje odluke o migriranju. U posljednjih nekoliko godina događa se epohalno masovno iseljavanje stanovništva iz zemalja Bliskog istoka. Većina migranata s tog područja ratni su prognanici i izbjeglice, odnosno prisilni migranti, no njima su se priključili i ekonomski (dobrovoljni) iz ostalih afričkih i azijskih zemalja, koristeći priliku i donedavno »otvorena vrata «nekih zemalja EU-a. Svi oni teže ne samo sigurnosti nego i boljem životu. Boljem životu, na što upućuju i rezultati ovog istraživanja, teže i oni koji iskazuju namjeru iseljavanja iz Hrvatske, no njihovu strukturu i motivaciju za iseljavanje tek treba podrobnije istražiti.

Ovo istraživanje pokazalo je da je u Hrvatskoj materijalizam kao vrijednost, iako nije apsolutno visoko zastupljena, razmjerno ravnomjerno raspoređena među stanovništvom, što znači da u većoj mjeri varira individualno nego u skladu sa statusnim obilježjima koja bi težnju za materijalnim dobrima mogla poticati ili biti njihovom posljedicom. Materijalističke vrijednosti nešto su istaknutije među mladima, a budući da je taj dio populacije ujedno i skloniji iseljavanju, provjereno je utječu li one na odlazak u usporedbi s odrednicama koje bi ga mogle olakšati ili otežati. Pokazalo se da je materijalizam relativno značajan i neovisan poticaj, pa se može zaključiti da bi njegov odnos s namjerama iseljavanja trebalo podrobnije ispitati vodi li se računa o relevantnosti obaju fenomena u današnjemu hrvatskom društvu. Ambicije ovog rada ne sežu dalje od iscrtavanja osnovnog i općeg obrasca. Kako bi se dobila detaljnija slika, a polazeći od nalaza koji upućuje na zaključak da i materijalizam i namjere iseljavanja više variraju među pojedincima nego među statusno heterogenim skupinama, bilo bi poželjno u budućim istraživanjima, prvo, izravno empirijski ispitati potpuni repertoar motiva iseljavanja na individualnoj (i profesionalnoj) razini i, drugo, utvrditi kakav je njihov odnos s pojedinim aspektima materijalizma kao (adekvatno ispitanoga) višedimenzionalnoga konstrukta. $\mathrm{Na}$ taj bi se način dobio temeljitiji uvid u širi spektar uzroka, motiva i poticaja za namjere iseljavanja te dobila objektivnija slika fenomena koji će dugoročno imati negativnije posljedice za razvoj hrvatskog društva. 


\section{LITERATURA}

Abercrombie, N., Hill, S. i Turner, B. S. (2008). Rječnik sociologije. Zagreb: Naklada Jesenski i Turk.

Adorno, T. W. i Horkheimer, M. (1980). Sociološke studije. Zagreb: Školska knjiga.

Ahuvia, A. C. i Wong, N. Y. (2002). Personality and Values Based Materialism: Their Relationship and Origins, Journal of Consumer Psychology, 12 (4): 389-402, doi: https:// doi.org/10.1207/s15327663jcp1204_10

Belk, R. W. (1984). Three scales to measure constructs related to materialism: Reliability, validity, and relationships to measure of happiness, Advances in Consumer Research, 11: 291-297.

Belk, R. W. (1985). Materialism: Trait Aspects of Living in the Material World, Journal of Consumer Research, 12 (3): 265-280, doi: https://doi.org/10.1086/208515

Bell, D. (1999). The Coming of Postindustrial Society: A Venture in Social Forecasting. New York: Basic Books.

Bilton, T., Bonnett, K. i Jones, P. (1987). Introductory Sociology. London: MacMillan.

Božić, S. i Burić, I. (2005). Migracijski potencijal Hrvatske - mikroanalitički aspekti. Migracijske i etničke teme, 21 (1-2): 9-33.

Brdar, I. i Anić, P. (2010). Životni ciljevi, orijentacije prema sreći i psihološke potrebe adolescenata: koji je najbolji put do sreće?, Psihologijske teme, 19 (1): 169-187.

Burić, I. (2010). Nacija zaduženih: od komunističkog pakla do potrošačkog kapitalizma. Zagreb: Naklada Jesenski i Turk - Hrvatsko sociološko društvo.

Burić, I. (2013). Banke: trgovci novcem kao arhitekti potrošačkog subjektiviteta, u: S. Čolić (ur.). Potrošačka kultura i konzumerizam. Zagreb: Institut društvenih znanosti Ivo Pilar, 107-124.

Campbell, C. (1987). The Romantic Ethic and the Spirit of Modern Consumerism. Oxford New York: Basic Blackwell.

Corrigan, P. (1997). The Sociology of Consumption. London: Sage.

Čolić, S. (2008). Sociokulturni aspekti potrošnje, potrošačke kulture i društva, Društvena istraživanja, 17 (6): 953-973.

Dević, I., Majetić, F. i Krnić, R. (2015). Vrijednosne preferencije hrvatskih građana kao odrednice materijalizma, Društvena istraživanja, 24 (4): 555-576, doi: https://doi. org/10.5559/di.24.4.05

Duda, I. (2005). U potrazi za blagostanjem: o povijesti dokolice i potrošačkog društva u Hrvatskoj. Zagreb: Srednja Europa.

Duda, I. (2010). Pronađeno blagostanje: svakodnevni život i potrošačka kultura u Hrvatskoj 1970-ih i 1980-ih. Zagreb: Srednja Europa.

Haralambos, M. i Heald, R. (1989). Uvod u sociologiju. Zagreb: Globus.

Hromadžić, H. (2008). Konzumerizam: potreba, životni stil, ideologija. Zagreb: Naklada Jesenski i Turk.

Hromadžić, H. (2012). Konzumeristički kapitalizam: epoha produkcije imaginarija potrošačke želje, Sociologija i prostor, 50 (1)[192]: 45-60, doi: https://doi.org/10.5673/ sip.50.1.3

Kaliterna Lipovčan, Lj., Prizmić-Larsen, Z. i Brkljačić, T. (2015). Materialism, affective states, and life satisfaction: case of Croatia, SpringerPlus, 4 (699), doi: http://doi. org/10.1186/s40064-015-1494-5 
Kamano, S. (1999). Comparing individual attitudes in seven countries, Social Science Research, 28 (1): 1-35, doi: https://doi.org/10.1006/ssre.1998.0630

Katunarić, V. (1974). Vanjske migracije i promjene u porodici. Zagreb: Centar za istraživanje migracija.

Krieger, H. (2004). Migration Trends in an Inlarged Europe. Dublin: European Foundation for the Improvement of Living and Working Conditions.

Lipovetsky, G. (2008). Paradoksalna sreća: ogled o hiperpotrošačkom društou. Zagreb: Antibarbarus.

Marx, K. i Engels, F. (1978). Rani radovi. Zagreb: Naprijed.

Maslov, G. (2009). Jean Baudrillard i Slavoj Žižek o potrošačkom društvu, Revija za sociologiju, 40[39] (1-2): 95-120.

Materialism, in: Oxford Dictionaries. Oxford University Press, http://oxforddictionaries. com/definition/english/materialism (02. 07. 2013.).

McKendrick, J. B. i Plumb, J. H. (1982). The Birth of a Consumer Society. London: Europa Publications Limited.

Mesić, M. (1991). Društveni razvitak i vanjske migracije u poslijeratnoj Jugoslaviji, u: M. Mesić i sur. Vanjske migracije i društveni razvitak. Zagreb: Institut za migracije i narodnosti, 9-34.

Mesić, M. (2002). Međunarodne migracije: tokovi i teorije. Zagreb: Filozofski fakultet, Zavod za sociologiju.

Mežnarić, S. (1991). Osvajanje prostora - prekrivanje vremena: migracije umjesto razvoja. Zagreb: Sociološko društvo Hrvatske.

Milas, G. (2007). Psihologija marketinga. Zagreb: Target.

Mileta, V. (1997). Stvara li se nova »željezna zavjesa« u Europi?, Politička misao, 34 (3): 24-30.

Müller, A., Smits, D. J. M., Claes, L., Gefeller, O., Hinz, A. i de Zwaan, M. (2013). The German version of the Material Values Scale, GMS Psycho-Social-Medicine, 10, (Doc 05), doi: http://doi.org/10.3205/psm000095

Nefat, A. i Benazić, D. (2014). Materijalizam, statusna i upadljiva potrošnja studenata u Hrvatskoj, Ekonomski pregled, 65 (3): 241-259.

Nefat, A. (2016). Smisao dobrovoljne jednostavnosti nasuprot konzumerizmu i materijalizmu, Ekonomski pregled, 67 (4): 350-368.

Nejašmić, I. (2014). Iseljavanje iz Hrvatske od 1900. do 2001.: demografske posljedice stoljetnog procesa, Migracijske i etničke teme, 30 (3): 405-435, doi: https://doi. org/10.11567/met.30.3.6

Peračković, K. (2013). Osnovni pojmovi u sociologiji potrošnje, u: S. Čolić (ur.). Potrošačka kultura i konzumerizam. Zagreb: Institut društvenih znanosti Ivo Pilar, 25-46.

Richins, M. L. (2004). The Material Values Scale: Measurement properties and development of a short form, Journal of Consumer Research, 31 (1): 209-219, doi: https://doi.org/10.1086/383436

Richins, M. L. i Dawson, S. (1992). A consumer values orientation for materialism and its measures. Scale development and validation, Journal of Consumer Research, 19 (3): 303-316, doi: https://doi.org/10.1086/209304

Rihtar, S. (2014). Materijalizam: dimenzije i istaknutost, u: Pilarov barometar hrvatskoga društva, srpanj 2014., http://barometar.pilar.hr/rezultati/standard-potrosnjamaterijalizam/materijalizam-dimenzije-i-istaknutost.html (20. 10. 2016.). 
Ritzer, G. (2005). Enchanting a Disenchanted World: Revolutionizing the Means of Consumption. Thousand Oaks - London - New York: Pine Forge Press.

Rogić, I. (2000). Tehnika i samostalnost. Zagreb: Hrvatska sveučilišna naklada.

Rogić, I. i Čizmić, I. (2011). Modernizacija u Hrvatskoj i hrvatska odselidba. Zagreb: Institut društvenih znanosti Ivo Pilar.

Segvili, F. i Cesur, S. (2014). The mediating role of Materialism on the relationship between values and consumption, Educational Sciences: Theory E Practice, 14 (6): 2083-2096, doi: https://doi.org/10.12738/estp.2014.6.2164

Stanić, S. (2011). (Post)socijalnost u suvremenom potrošačkom prostoru, Sociologija $i$ prostor, 49 (1)[189]: 3-23, doi: https://doi.org/10.5673/sip.49.1.1

Veblen, T. (2008). Teorija dokoličarske klase. Novi Sad: Mediterran Publishing.

Wertheimer-Baletić, A. (1999). Stanovništvo i razvoj. Zagreb: Mate.

Wong, N., Rindfleisch, A. i Burrougs, J. E. (2003). Do reverse-worded items confound measures in cross-cultural consumer research? The case of material values scale, Journal of Consumer Research, 30 (1): 72-91, doi: https://doi.org/10.1086/374697

\section{IZVORI}

Migracija stanovništva Republike Hrvatske u 2013., Priopćenje 7.1.2, Državni zavod za statistiku, Zagreb, 2014.

Migracija stanovništva Republike Hrvatske u 2014. Priopćenje 7.1.2, Državni zavod za statistiku, Zagreb, 2015.

Migracija stanovništva Republike Hrvatske u 2015. Priopćenje 7.1.2, Državni zavod za statistiku, Zagreb, 2016.

Statistički podaci. Hrvatski iseljenički adresar, http://www.hia.com.hr/iseljenici-statistika. html (20. 03. 2016.). 


\title{
Materialism as a Social Value and Impetus for Intentions to Emigrate from Croatia
}

\author{
Krešimir Peračković, Stanko Rihtar
}

\section{SUMMARY}

The paper discusses materialism as a value orientation and background of consumerism, and empirically verifies whether it is connected with the intentions to emigrate from Croatia.

The starting point is the definition of materialism as a social value, i.e. belief that the possession of material objects is important, profitable and worthwhile, while consumerism includes dynamic dimension of it or actions focused on achieving these goals. Besides, consumerism is also defined as a culture centred on the promotion, sale and acquisition of consumer goods. From this perspective materialism may be considered an infrastructural value of contemporary consumer culture on a general level, as well as an encouragement of consumer behaviour on an individual level. This primarily means a wider aspect of consumption that goes beyond achieving basic needs, such as existential needs for matter and energy. However, in order to achieve a certain standard of consumption, to ensure access to material goods and climb the consumption ladder, the necessities for such an achievement (or modes of consumption) often cannot be provided according to actual (local) living conditions. Thus, there is a tendency toward improving conditions, higher earnings and generally better quality of life, as one of the most important motives for economic migration. In this way, horizontal mobility - emigration, becomes a tool that provides the vertical social mobility. In this respect materialism takes a dual role: on the one hand it is an infrastructural value of consumer culture, and on the other it is a possible incentive for emigration. This paper tries to give empirical answers to the following questions: 1) Are materialism and emigration correlated, and 2) Does materialism encourage emigration (if aspirations cannot be fulfilled in domestic society)?

Consumerism, as a globally relevant phenomenon, is also present locally, in Croatian society, as well as another relevant phenomenon, but less universal - emigration.

Croatia is a "traditional" emigration country, with unfavourable ratio of expatriate and resident population (it is estimated that the total number of emigrants equals the number of those who live in Croatia). If emigration had not been so intensive and did not last for more than a century, demographic analyses show that at least 6.22 million people would live in Croatia in 2001 or $40.1 \%$ more than today (Nejašmić, 2014). Taking into account a longer historical period, the Ottoman and other conquests (only the Ottoman threat lasted for four centuries), both World Wars and the Croatian War of Independence in the late $20^{\text {th }}$ century, the geo-strategic position (the area of inter-civilizational conflicts or rally of the major political forces) made Croatia a long-term scaffold, so forced emigration often meant saving lives (Rogić, 2000). In addition, scarce technical modernization and the nature of political associations in which Croatia had secondary political role completed the repertoire of motives for emigration: besides saving lives, people emigrated for economic, political and career reasons (Rogić and Čizmić, 2011).

In addition to demographic approach, sociology of migration deals with the broader 
context and background social factors of migrations, including particular motives of migrants (e.g. Mesić, 2002; Mežnarić, 1991; Mesić et al., 1991; Katunarić, 1974). The literature dealing with this topic is not scarce, but there is a lack of research and analyses focused on a recent wave of emigration from Croatia in more detail, especially after joining the EU. However, it is known that higher earnings, primarily in Western Europe and the United States, are a permanent feature of voluntary and economic migration from Croatia or pull factor. For example, Mesić pointed out that the most agile part of labour force, including a substantial part of those already employed (mostly skilled or highly skilled workers) emigrated by the end of the 1960s. For example, a 1971 survey showed that $77 \%$ of emigrants had been previously employed and their main motive for emigration were higher earnings (Mesić, 1991). The thesis on unemployment as the main cause of emigration has not proved to be true even at that time, and this issue is of equal importance today: is emigration primarily motivated by "survival" or by intention to achieve some "surpluses" (material and/or professional). In relation to the earlier period, current emigration occurs in a very different context. The global economic crisis, present in Croatia as well, may not be the most important factor, considering the fact that crisis in general (or lack of professional perspectives) in the underdeveloped country is actually "permanent status". But the political context is significantly different: after political transition, and especially after joining the EU, barriers to mobility have almost been eliminated, and this probably triggered a new wave of emigration.

According to media headlines, a new wave of emigration from Croatia has reached alarming proportions (in some cases estimations rise up to two hundred thousand people). Official statistics is more moderate: annual records of the Central Bureau of Statistics show that 15,262 people emigrated in 2013, 20,858 in 2014 and 29,651 in 2015 (CBS, 2014, 2015, 2016). However, these records are based on data on the cancellation of residence by the Ministry of the Interior, but since these changes are only partly reported (or at least not immediately), it should be assumed that the numbers are certainly higher. According to available analyses of experts, such as the one of Župarić-Iljić (Institute for Migration and Ethnic Studies), those data are not catastrophic, especially when compared with the multimillion departures from Poland or Romania after EU accession. But concern remains: the trend is rising and often whole families are leaving, without intention to return.

Although the emigration of the unemployed and unskilled has negative demographic consequences, the emigration of highly educated (and already employed) experts (brain drain) is harmful to an even greater extent, because the socio-economic damage is twofold: first, it lowers developmental potential and quality of life in local communities, and second, investment in the education of those who left becomes futile.

Besides these objective circumstances and "traditional" motives, current emigration may be encouraged by materialism (materialistic values) as a latent motive. The aim of this paper was to empirically determine if this is the case. Data for analysis were collected in 2014 by face-to-face survey on a representative sample of adult population of Croatia $(\mathrm{N}=1000)$. Results showed that materialism was relatively low prominent but it had become an evenly distributed (universal) value among the population, which means that to a greater extent it varies individually rather than between relevant socio-demographic and status groups. Younger generations are the exception: they are slightly more materialistic and their intentions to emigrate are much more prominent than among older (40 years and over) segments of 
population. Likewise, in the cohorts younger than 40 materialism is a significant and independent predictor of intentions to leave, in comparison with other more or less relevant objective (education level, employment, income, type of dwelling, relatives abroad, marital status, number of children) and subjective predictors (satisfaction with one's own personal standard and general situation in Croatia).

Finally, it is concluded (with regard to the relevance of both phenomena in today's Croatian society) that relationship between materialism and (intended and actual) emigration should be further examined.

KEY WORDS: materialism, consumerism, social values, emigration from Croatia, economic migrants 